\title{
Political engagement in the writings by Margaret Atwood and Dionne Brand
}

\author{
Aline de Mello Sanfelici ${ }^{*}$
}

\begin{abstract}
Resumo
Este trabalho discute escritos poéticos de Margaret Atwood e de Dionne Brand em relação aos escritos teóricos das mesmas autoras, alinhados com outras referências teóricas pertinentes, com o propósito de demonstrar como Atwood e Brand produzem trabalhos politicamente engajados. $O$ argumento central é que as autoras em questão denunciam formas de violência e marginalização de sujeitos em processos de colonização e imigração, assim desenvolvendo escritos que, ao invés de silenciarem, dão voz a problemas contemporâneos.
\end{abstract}

\section{Palavras-chave}

Margaret Atwood. Dionne Brand. Engajamento político. Colonização. Imigração.

\section{Introduction}

Joseph Brodsky once said that literature is all continuity, all echo. Given the premise that an author's pieces of literature can express his/her political concerns and agenda, I discuss in this essay two authors, namely, Margaret Atwood and Dionne Brand, and the perspectives and political engagements they develop in some of their poems. Additionally, I seek to demonstrate that the engagements developed in the selected poems align with Atwood's and Brand's non-fictional writings. My point is to show that Atwood and Brand construct a political agenda that works for the denouncement of forms of oppression and violence that typically occur in processes of immigration and colonization.

To get started, let me present a working definition of the main terms to be discussed. One of the main issues in my discussion, that is, colonization, shall be referred to as the populating of a given area through the establishment of colonies, done by people from a different (foreign) country. To colonize is to get established in some place and populate this location, settling down on it. The concept of colonization differs from that of colonialism, though the two may be frequently related to each

\footnotetext{
* Doutora em Letras/Inglês e Literatura Correspondente - UFSC
} 
other: colonialism is understood as exploitation by a stronger group of a weaker one, causing hierarchies and victimization. Many times, colonialism is the result of colonization processes, in such a way that both colonization and colonialism lead to appropriation and marginalization, and sometimes even extermination of cultures.

Connected to the notion of colonization, other concepts that need to be defined now are those of "explorers" and "settlers". Explorers search or travel through a place for the purpose of discovery, to examine, research, and then leave. They are often guided by purposes of adventure and observation, in such a way that there is not much interference as there is contemplation. Settlers, in turn, aim at going to a place to live and establish themselves there. That is, settlers inhabit, plant, and build in the new place, consequently changing and interfering on it. Their goal is to establish a colony, populating and possessing the land. Settlers, in other words, are the ones who colonize, whereas explorers merely explore. I later argue that these definitions meet Atwood's own definitions shown in her poems and theoretical postulations.

The notions of in-betweeness and displacement, in turn, are referred to in the present discussion as distinct but close terms. In a simplified view that does not account for all the specificities peculiar to the situation, to be or to live in-between cultures is to find oneself in a position of displacement in which one cannot return to a previous land or reality - even if this return takes place, the person who returns is already changed, due to the experiences of displacement, and the land or reality to which one returns to is also different, being therefore impossible to return to the exact previous condition. At the same time, this subject does not actually "belongs" to the new land or reality, precisely for being forever someone from the outside, a foreigner. Thus, he/she is displaced and in-between cultures, languages, positions and realities.

Finally, concerning the notion of the hyphen, Homi K. Bhabha defines it as what both "binds and divides... both compounds difference and underlines sameness," as put forth by Fred Wah (2001, p. 72-73). Wah further illuminates the concept, saying: "though the hyphen is in the middle, it is not in the centre... [it is] a no man's land, a nomadic, floating magic carpet, now you see it now you don't" (2001, p. 73). In this sense, the hyphen signals plurality - of meanings, possibilities, identities, locations. Moreover, this plurality does not need to be shown or developed all the time, that is, it can be a magic carpet in which aspects of the hyphen are seen at certain times and hid at others, for strategic purposes. In other words, the hyphen, this plurality, the separation and union through the dash, can work as a survival tool in struggles against violent colonization and displacement caused by colonization or immigration processes. This, and the other concepts here defined, appears in more detail throughout the analysis that follows, of the selected writings by Atwood and Brand.

\section{Margaret Atwood's Native Perspective Against Colonization}

In this section I propose a dialog between Atwood's poems "The Explorers" and "The Settlers" with some of Atwood's theoretical postulations regarding colonization; in-betweeness (as connected to displacement); and the hyphen. As I develop the proposed dialog, other issues emerge, such as appropriation and marginalization of peoples and extermination of cultures, issues that are important for being related to the results of the colonization of the wilderness and the interactions between 
colonizers and colonized ones. These issues, in fact, are precisely what the author wants to denounce, for it is my claim that Atwood voices the silent dash of the native, by taking a positioning in favor of the native people who watch their land being either explored or colonized (settled) by foreigners.

As Charlotte Beyer states, for Atwood colonialism is oppressive, and for this reason Atwood articulates certain tools of survival, which can be observed in her writings. One such tool is a strategic relationship between body and place. Another is to treat precisely the problematic themes that pertain to one's agenda. Yet another, following Beyer, has to do with Laura Mulvey's observance that "national identity is a point of resistance, defining the border fortifications against exterior colonial penetration" (1995, p. 97). Hence, Atwood uses "discursive and thematic" tools in her writing as a way to resist colonialism and "imported imperial cultures" (1995, p. 99).

In the poem "The Settlers" Atwood writes: "A second after/the first boat touched the shore, /there was a quick skirmish /brief as a twinge /and then the land was settled". It seems that Atwood was ironical to say that the conflict ("skirmish") was "quick" and "brief." The irony is that it is probably less painful to be the one who arrives to possess or appropriate something than to be the one who has one's land invaded by others. Also, by saying that there was this skirmish, even if it were a quick one, Atwood indicates resistance to violent settling of foreigners in one's territory. Moreover, given the title of the poem and its content, Atwood clearly defines settlers in the same terms as I have defined earlier - as those with goals of colonization (inhabiting a place), in a process that may cause suffering and violence.

Keeping in mind the way settlers are conceived in this poem, let us see how Atwood differentiates explorers from settlers in explicit terms, in a non-fictional work called Survival. While the explorers experiment the land and the supposedly chaos of the wilderness, and "emerge from it" later; the settlers interfere more in the place, for, as Atwood states, settlers "do not move through the land, they go to one hitherto uncleared part of it and attempt to change Nature's order (which may look to man like chaos) into the shape of human civilization" (1972, p. 120). In other words, explorers act more in the name of discovery and perhaps even adventure, for a temporary period; whereas settlers aim at colonizing the land, by inhabiting it and appropriating it to their own type of civilization. In this regard, Atwood's Survival calls attention to dangers of modernization such as the loss of identity (of a place, for example), and also criticizes the colonizers' abrupt imposition of their patterns of civilization on a land that is not theirs. Hence, we see here an instance of how Atwood's poetry and nonfictional writing put forward similar concerns.

The theoretical notion of settlers found in Survival and explored in the poem "The Settlers" is also present in Atwood's fictional work The Journals of Susanna Moodie. In this other work, Atwood fictionally impersonates Moodie, a real immigrant to Canada, and voices her poetic persona as someone who is at first lost in the wilderness of the new country and ends up inhabiting it as a settler (though a settler who cannot escape the wilderness, for the wilderness becomes part of her). In this sense, Atwood again defines settlers as those who inhabit and change the place, through her portrayal of Moodie's life and experiences in Canada, in a work that also gives visibility to the themes of in-betweeness and displacement of immigrants. 
It can be noticed, therefore, that Atwood's theoretical differentiation (in Survival) between explorers and settlers matches the working definitions I presented earlier, and the definitions in her fictional work The Journals and her poem "The Settlers." In another poem, titled "The Explorers", Atwood writes that the explorers "will be jubilant /and shout, at finding /that there was something /they had not found before /although this island will afford /not much more than a foothold: /little to explore". In this passage it seems that the explorers, who do not intend to inhabit the land, will be busy observing it, only, and there will not be too much to explore/observe. Also, the words "jubilant" and "shout" signal that the little exploration that the explorers can do suffices for them to feel satisfied. In other words, the explorers will be glad simply to find new things ("something they had not found before"), with no references of settling down.

These examples from both fictional and non-fictional writings by Atwood show that explorers and settlers are indeed different, for the former observes with little interference whereas the latter causes the natives to be displaced from their original land - the natives are found "inland, stranded /on a ridge of bedrock," after the settling down of the foreigners. In other words, the processes of colonization cause not only interferences in the land itself, which acquires the shape of European cities, but also in the lives of the native peoples. In this way, colonization and modernization bring not only the so-called progress, but disturbances and complications for the natives, as well. And this is precisely what Atwood attempts at denouncing and calling attention to.

Atwood also develops in Survival the idea that settlers try to "fix" Nature, which is "labyrinthine, complex, curved" (1972, p. 120), by trying to make it fit into straight lines and patterns. In this sense, she proposes that "the Canadian pioneer is a square man in a round whole" (1972, p. 120), who insists on adapting Nature to human civilization while actually it should be the other way round - adapting civilization to nature. Again, Atwood's theoretical proposal may be found in the poems discussed. Specifically in "The Settlers" Atwood writes of this group of people "defining [the natives'] own island," that is, the settlers are establishing elements and patterns that match their experience in European civilization as if there were a problem or something to be corrected or fixed in the native's land. Thus, Atwood's poems and theories are aligned once more.

The consequences of colonization and urbanization to the natives, that is, their displacement and their living in-between, may be noticed in the poems once more, in the moment in which the native's situation is portrayed as follows: "They [the settlers] dug us [the natives] down /into the solid granite / where our bones grew flesh again, /came up trees and /grass". This passage signals the appropriation of the land by the settlers and the extermination of the native's culture and even lives. However, the passage also shows that there will always be the native's blood and history attached to the place - even if the natives bodies are killed or displaced! Atwood's articulation here of the body linked to struggle against the oppressions of displacement through colonization aligns with Beyer's reading of Atwood's works, mentioned before, in which it was pointed out that Atwood makes use of a strategic relationship between body and place to struggle for the survival of native peoples. This is another indication of the alignment between Atwood's poetic and theoretical writings. In addition, it is crucial to 
observe that Atwood approximates herself to the native's perspective by using a poetic persona that speaks as a member of the native group - "they dug us down" (emphasis added).

The issues of the body and the extermination of cultures are found in her poems in other passages. Some examples are the mentioning of "skeletons" and "gnawed bones" in "The Explorers," and the terms "ribs," "carcass" and again "skeleton" in "The Settlers." As can be seen, both poems address the damages of colonization and its violence which leads to extermination of cultures - claims that Atwood emphatically articulated in Survival. In other words, Atwood uses her poetical writings to side with the natives and problematize the aggressive process of colonization and appropriation to which native people were and still are often submitted to. It is in this sense that I claim that Atwood assumes the native's perspective.

Further into the displacement and in-betweeness of natives by the presence of colonizers, and the natives' victimization, there is another relevant passage in "The Settlers" that I would like to highlight: the natives, after the arrival of the pioneers, are "drifted /picked by the sharks." This may be understood as a reference to the living on the margin of the dominant culture, that is, the falling to the bottom of the hierarchy created by the oppressive process of colonization and urbanization of places. In the passage just mentioned, Atwood once more sides with the native people, and even includes herself (her poetic persona, at least), as one of them, to highlight a positioning against the damages of violent colonization and displacement of natives - a positioning she takes in her theoretical writings, too, as exposed earlier.

What I hope to have made clear throughout this discussion is that Atwood uses her poetical writings to side with her theoretical claims: Atwood's positioning against the damages of colonization and appropriation, her struggle against oppression and marginalization of native peoples, are topics found in both her theoretical writings such as Survival and her poetic writings, such as "The Explorers" and "The Settlers". In this way, her poems are used as strategies for survival, strategies to voice the natives and problematize violent traditions that took and still take place around the globe.

\section{Dionne Brand's Warning About the Difficulties of Immigration}

After a focus on native peoples who face processes of colonization of their own lands, let us now see issues of displacement and assimilation specifically regarding immigrants, who go to a different, foreign land. I discuss these issues specifically in the light of Dionne Brand's poem "We believed in nothing," a poem that is an expression of discontentment and critique to the colonization of immigrants in Canada. First, however, I explore in detail the positioning defended by Brand in her theoretical writings.

Brand argues in A Map to the Door of No Return that the only homogeneous aspect within Canadian identity/ies is the agreement that such homogeneity does not exist. Brand ironically submits that there is an official Canadianness which "functions to exclude as it functions to define... it excludes and evades immigrants, regardless of their length of citizenship, either through race or language" (2001, p. 137). Following 
Brand, this idea implies erasing the immigrants' previous lives and histories due to the "not-where-you-come-from-but-better morality" (2001, p. 138), that is, immigration is (problematically) conceived as necessarily "fleeing a horrible past/place and arriving gratefully at an unblemished present/place" (2001, p. 138, emphases added). This perspective ignores that immigration can actually be a choice, and ignores, also, the fact that immigrants can (and as Brand shows, they do) face great difficulties in the new place, difficulties that may not leave them necessarily "grateful."

Further, the attempt at erasing the immigrants' memories exemplifies what Nikki Sullivan exposes as the assimilationist approach to cultures in processes of colonization and subalternity. Sullivan argues that assimilationism works towards an ideal of a subject being "assimilated" into a dominant culture so as to become part of it (2003, p. 23). This means that assimilationists believe that "superior" elements can "assimilate" other elements conceived as "inferior" in such a way that after the process of assimilation, there are no longer distinct groups, only one (allegedly) homogenized group.

It is necessary to realize that this approach is limiting because it maintains and perpetuates notions of hierarchy and asymmetrical power relations of superiority and inferiority. Further, it clearly reinforces the binaries of colonizer/colonized and dominant/dominated, being such binaries sites for discrimination and oppression specifically, of immigrants, who end up being marginalized. Sonia Torres suggests other critiques to assimilationism, claiming that the understanding of one culture/value/subject being "assimilated" by another, and therefore having its/his/her specificities erased and "corrected" or "adapted" to the mainstream culture causes assimilationism to be elitist (2005, p. 726) and therefore inevitably oppressive to those who "need" to be assimilated. Another problem with the assimilationist politics is that it acts in the name of convenience, that is, it is conservative and therefore not open for knowledge and transformation, i.e., it is not open for inclusion of other necessities and non-homogeneous identities.

Specifically considering immigrants in Canada and the issues of nonhomogeneous identities, assimilationism, and the duality between dominant and dominated ones, Brand argues that immigrants are given silence as their discourse (this is the option they have), which suggests a subaltern positioning for immigrants and the attempt to assimilate them. As Brand puts it, there is a dominant voice - the voice of the colonizers - that "claim[s] to speak for all. A dominant voice that needs not of course all of our consent - our silence or our repressed voice is sufficient" (2001, p. 141). Further into that, Brand exposes that "the idea of a homogeneous culture in Canada today seems to me not only a dead end... but also a hegemonic strategy of capital to produce a 'pure' identity to be filled up with commodities and pumped up to defend economic threat by other corporate-run states" (2001, p. 144145).

Taking into account that there is no homogeneity in identity (neither in Canadianness), and that assimilationism is problematic, elitist and a form of violence against the identities of those who suffer it, let us now see how Brand voices these stances in her poem "We believed in nothing." This poem carries in its own title at 
least two positionings - that of immigrants who do not engage entirely in the so-called dominant culture of the place to which they immigrated, and that of people who were forced to forget their pasts and therefore ended up with no histories and own beliefs. In the first case, the immigrants chose not to be assimilated and not to "buy" the conventions and traditions of the dominant culture. In this way, they believed in nothing related to the supposedly "pure" Canadian identity. In the second case, the immigrants lost their memory (by force) and believed in nothing, but what was told to them by the dominants. Regardless of other possible positionings implied solely by the title of the poem, still one may argue that immigrants in this poem either suffered or resisted suffering processes of assimilation.

After this debatable title, the poem starts with the following verses: "the blackand-white american movies /buried themselves in our chests." This idea indicates that the American movie industry - and possibly American values and culture, attached to and conveyed by such movie industry - influenced the lives of those who have had access to it. In other words, the initial verses of the poem show the hegemonic American movie industry affecting those who are submitted to it, being such industry buried into people's chests.

The second stanza mentions Western movies and the stereotypical plot in which cowboys are heroes and superior for being good, and Indians are villains and inferior due to their bad inner characters. In the context of the poem being written by Brand and considering also her cultural critiques, this stereotypical plot is analogous to the dominant peoples being the cowboys and the immigrants in Canada being the Indians. When Brand mentions "the homicides of Indians, /lit, dimmed, lit, dimmed" in the second stanza, she may be denouncing the "killing" that assimilationism causes to immigrants. She is probably ironic to the fact that oftentimes immigrants are not well seen and received, and are treated as if they were villains, or invasors, who must be "killed" (at least in their identities and trajectories, that become erased by the mainstream culture). Therefore, Brand is critical of the impossibility of migration without prejudices and forms of oppression. For Brand, there is not only prejudice face to immigrants, as there is also the damages of a tentative forged sameness - since immigrants are silenced or someone else speaks for them, the immigrants' own struggles, realities, and memories are misrepresented and even erased in detriment of a pure (and illusionary) Canadianness.

In a more explicit phrasing, the next stanzas of the poem tell the arrival of immigrants and how problematic and hard it is to live as such: "we arrived spectacular, tendering /our own bodies intro dreamery, /as meat, as mask, as burden" (fourth stanza), "like chaos" (fifth stanza). The comparison of this arrival to chaos suggests the difficulties faced by immigrants, since they "have" to forget their past and pretend a Cannadianness that does not exist. And this falsehood is portrayed in the very following stanza, supporting the idea of a chaotic arrival (and life) as an immigrant: "all the fake feelings we had, oh love, /the acts of ventriloquism," being the word "ventriloquism" the vehicle to convey the notion of falsehood and forged identity. 
The life of immigrants continues to be portrayed in the sequence of the poem, as it reads: "we returned home dead on our feet /and melancholy." Brand may be suggesting here the melancholy as a result of a life of dishonesty, for the immigrants are considered non-Canadians and at the same time, in the eyes of the Canadians-bybirth, are considered without a past and a previous place. Thus, the next stanza goes: "the earth was never the earth, /we were never anyone," conveying the idea that regardless of the experiences lived before Canada and in Canada, still the immigrants would be seen merely as "immigrants" - those who do not belong here (in Canada) and are not there (where they are from). These last verses show how immigrants are excluded and marginalized, for being always seen as "others" and "from another place," "not here," as Brand argues in "Imagination, Representation and Culture." Finally, the fact that the immigrants "were never anyone" conveys the criticism to the idea that the immigrants were inferior, because they were no one, and in being inferior to the Canadians and colonizers, they would submit to the morality named by Brand as "not-where-you-are-from-but-better." Such morality reinforces the wrong notion that to migrate is necessary so as to find a better life, and ignores the fact that migration may as well be a choice and the immigrants' life may be hard, or even harder, than before migrating.

As could be observed, Brand's poem "We believed in nothing" portrays the difficulties experienced by immigrants in Canada as they suffer prejudices, are forced to get adapted into a homogeneous and therefore false "Canadianness," and in the process of immigration need, frequently, to discard their past and values. In other words, it is clear that Brand's poem gives a warning about dangers related to immigration, particularly in light of processes of assimilationism and the consequent erasure of cultures. Brand is critical to such processes that ignore the actual choices for migrating and that force immigrants to "become like" someone they are not. Such concerns are part of Brand's political agenda, as can be noticed in her theoretical texts and in this poem in particular.

\section{Final Remarks}

As we have seen, both Atwood and Brand develop politically engaged writings, in their fictional and non-fictional works. In other words, it was demonstrated that their writings are not naïve or alien to the violences experienced by marginalized groups, being that each author focuses on a different situation (natives being colonized and immigrants, respectively). Given the political engagement expressed in their literature, Atwood and Brand could be considered hybrid writers in the sense put forth by Wah, that is, writers who are able to "develop instruments of disturbance, dislocation, and displacement" (2001, p. 73). Hence, for siding with oppressed groups and calling attention to issues that need to be put in the foreground of cultural studies today, Atwood and Brand's perspective is surely that of making noise instead of silencing, and problematizing instead of harmonizing. 


\section{Referências}

ATWOOD, Margaret. Survival: A Thematic Guide to Canadian Literature. Toronto: McClelland and Stewart, 1972.

Selected Poems, 1966-1984. Toronto: Oxford University Press, 1990.

BEYER, Charlotte. "From Violent Duality to Multi-culturalism: Margaret Atwood's PostColonial Cultural and Sexual Politics." Jorn Carlsen (ed). O Canada: Essays on Canadian Literature and Culture. Aarhus: Aarhus University Press, 1995.

BRAND, Dionne. A Map to the Door of No Return. Toronto: Doubleday Canada, Random House of Canada Ltd., 2001.

"Imagination, Representations and Culture." Bread Out of Stone. Toronto:

Couch House Press, 1994.

Inventory. Toronto: McClelland \& Stuart Inc., 1997.

SULLIVAN, Nikki. A Critical Introduction to Queer Theory. New York: New York University Press, 2003.

TORRES, Sonia. "La Conciencia de la Mestiza /Towards a New Consciousness - uma conversação inter-americana com Gloria Anzaldúa." Revista Estudos Feministas, CFH/CCE/UFSC 13:3 (2005): 720-737.

WAH, Fred. Faking It. Poetics and Hybridity. Edmonton: NeWest Press, 2001.

\section{Title}

Engajamento político nos escritos de Margaret Atwood e Dionne Brand

\section{Abstract}

This essay discusses poetic writings by Margaret Atwood and by Dionne Brand in relation to the theoretical writings by the same authors, aligned with other pertinent theoretical references, with the objective of demonstrating how Atwood and Brand produce works that are politically engaged. The central thesis is that the authors in debate denounce forms of violence and marginalization of subjects in processes of colonization and immigration, developing, in this way, writings that instead of silencing actually voice contemporary problems.

\section{Keywords}

Margaret Atwood, Dionne Brand, political engagement, colonization, immigration.

Recebido em 18.04.2011. Aprovado em 11.07.2011. 